\title{
POTRET KEMISKINAN \\ Dalam Dimensi dan Karakteristiknya
}

\author{
Siti Aisyah Tri Rahayu \\ Fakultas Ekonomi Universitas Sebelas Maret Surakarta
}

\begin{abstract}
This paper's aim to explain the poverty and policy, particularly in developing world. This article will try to analyze poverty and its measure, characteristics and policy to solve it. From the available data, we know that the poverty in Indonesia has been declined very dramatic until 1996, before the economic crisis. Through the crisis, there are a large number of people below poverty line is increase. However, poverty is always became a center of problem in macroeconomic that must be reduce to bring people to get welfare economics. And, there are many policies to solve the poverty problem that we can adopt to reduce poverty.
\end{abstract}

Keywords: poverty gap, poverty measurement, welfare economic, poverty line, reduce poverty policy

\section{DEFINISI KEMISKINAN}

Istilah "kemiskinan" muncul ketika seseorang atau sekelompok orang tidak mampu mencukupi tingkat kemakmuran ekonomi yang dianggap sebagai kebutuhan minimal dari standar hidup yang tertentu. Di negara sedang berkembang (NSB), kemiskinan biasanya dihubungkan dengan masalah kemakmuran (welfare economics) yang merujuk kepada konsumsi barang dan jasa.

Ilmu ekonomi secara esensial pada dasarnya adalah studi tentang kemiskinan (Hartwell, 1972:3 dalam Chenery, 1995:2553) . Analisis mengenai kemiskinan ini mempunyai tiga tugas yaitu:

1. Mendefinisikan dan menggambarkan "kemiskinan"

2. Memahami apa penyebabnya

3. Menginformasikan kebijakannya.

148 Jurnal Ekonomi Pembangunan Vol.2, No.2, Desember $2001: \overline{148-160}$ 
Dalam tulisan ini akan dibahas mengenai bagaimana cara mengukur kemiskinan, apa ciri-cirinya dan bagaimana penanggulangannya.

\section{PENGUKURAN KEMISKINAN}

Ada tiga pertanyaan mendasar yang harus dijawab oleh seorang ekonom ketika ia akan mengukur kemiskinan yaitu:

1. Bagaimana kita menaksir kesejahteraan secara individual atau "tingkat kemakmurannya"?

2. Pada tingkat ukuran kesejahteraan berapa kita katakan bahwa seseorang itu tidak miskin?

3. Bagaimana kita meng"agregasi"kan indikator kesejahteraan individual ke dalam ukuran kemiskinan?

Pada umumnya indikator yang dipilih dalam mengukur standar hidup rumah tangga adalah lebih menekankan kepada mengukur konsumsi riil saat ini, yang ditentukan oleh seluruh harga tertimbang di semua pasar komoditi yang dikonsumsi oleh rumah tangga dari seluruh sumber (pembelian, pemberian dan produksi sendiri).

\section{A. Ukuran kemiskinan}

Ada tiga ukuran utama yang diusulkan oleh Foster, Greer dan Thorbecke (1984) dalam Lipton (1995). Ukuran itu adalah:

1. Head-count index $H$

2. The poverty-gap index $P G$

3. The Foster-Greer-Thorbecke $P_{2}$ measure

\section{Head-count index $H$}

Index ini digunakan untuk mengukur kemerataan kemiskinan. Ukuran sederhana dari index ini adalah ditentukan oleh proporsi dari populasi terhadap konsumsi seseorang (y) lebih kecil dari garis kemiskinan (z). Andaikan $\mathrm{q}$ adalah orang yang miskin dalam populasi n, maka Head-count index adalah:

$\mathrm{H}=\mathrm{q} / \mathbf{n}=$ proporsi dari total populasi yang dianggap miskin.

\section{The poverty-gap index $P G$}

Ukuran yang lebih baik adalah poverty gap, yang didasarkan pada selisih kemiskinan agregat dari kemiskinan relatif pada garis 
kemiskinan. Ini memberikan indikasi yang baik dalam hal kedalaman kemiskinan, dimana hal ini tergantung kepada jarak kemiskinan di bawah garis kemiskinan.

Ukuran ini mendefinisikan konsumsi yang sedang menaik, orang miskin mempunyai $y_{1}$, miskin berikutnya $y_{2}$, dan seterusnya, sampai dengan orang miskin terakhir $y_{q}$, yang tidak lebih besar dari garis kemiskinan z. Sehingga poverty gap index bisa dituliskan sebagai berikut:

$$
P G=\frac{1}{n} \sum_{i=1}^{q}\left[\frac{z-y_{i}}{z}\right]=\begin{aligned}
& \text { proporsi rata-rata poverty gap di antara } \\
& \text { seluruh populasi (zero gap untuk yang } \\
& \text { tidak miskin) }
\end{aligned}
$$

ini dapat juga ditulis sebagai

$$
\mathrm{PG}=\mathrm{I} . \mathrm{H}
$$

dimana I menunjukkan "income gap ratio" yang didefinisikan sebagai:

$$
I=\frac{z-y^{p}}{z}=\begin{aligned}
& \text { rata-rata kedalaman kemiskinan sebagai } \\
& \text { proporsi dari garis kemiskinan }
\end{aligned}
$$

\section{The Foster-Greer-Thorbecke $P_{2}$ measure.}

FGT $P_{2}$ adalah poverty gap dari orang miskin yang ditimbang dengan poverty gapnya untuk menaksir kemiskinan agregat. Jadi:

$$
P_{2}=\frac{1}{n} \sum_{i=1}^{q}\left[\frac{z-y_{i}}{z}\right]^{2}=\text { rata kuadrat dari proporsi poverty gap }
$$

Dengan membandingkan rumus ketiga $H, P G$ dan $P_{2}$ di atas, strukturnya menjadi jelas dengan menggolongkan ke dalam ukuran tambahan secara umum:

$$
P_{\alpha}=\frac{1}{n} \sum_{i=1}^{q}\left[\frac{z-y_{i}}{z}\right]^{\alpha}
$$


untuk $\alpha$ adalah parameter non-negatif.

Ini adalah ukuran kemiskinan dari Foster-Greer-Thorbecke (Foster, 1984). $P_{\alpha}$ adalah rata-rata dari seluruh populasi dari ukuran kemiskinan individual dimana mempunyai nilai $\left[\frac{1-y_{i}}{z}\right]^{\alpha}$ untuk orang miskin dan nol untuk non-miskin.

Ada ukuran kemiskinan tambahan lainnya, yaitu:

$$
p=\sum_{i=1}^{n} p\left(\frac{z, y_{i}}{n}\right)
$$

dimana $\mathrm{p}\left(\mathrm{z}, \mathrm{y}_{\mathrm{i}}\right)$ adalah ukuran kemiskinan individual, bernilai nol untuik non-miskin $\left(y_{i}, z\right)$ dan bernilai positif untuk si miskin nilainya adalah fungsi antara garis kemiskinan dan standar hidup individual (Atkinson, 1987)

\section{KARAKTERISTIK DAN DIMENSI KEMISKINAN}

\section{A. Potret Global Kemiskinan}

Menurut World Development Report 1990 (WDR, 1990), pada tahun 1985 sekitar 1,1 milyar orang di negara sedang berkembang (NSB) hidup dalam kemiskinan. Dari angka ini sejumlah 633 juta orang tergolong sangat miskin, perkiraan ini mendasarkan pada pendapatan $\$ 375$ per kapita per tahun untuk golongan miskin dan $\$ 275$ per kapita per tahun untuk golongan sangat miskin (konstan pada harga 1983)

\section{B. Kriteria Kemiskinan}

Kemiskinan mempunyai dua kriteria yaitu kemiskinan absolut dan kemiskinan relatif. Kemiskinan relatif yaitu penduduk yang memiliki pendapatan sudah mencapai tingkat kebutuhan dasar, namun jauh lebih rendah dibanding keadaan masyarakat sekitarnya. Sedangkan kemiskinan absolut yaitu kemiskinan yang diukur dengan tingkat pendapatan yang dibutuhkan untuk memenuhi kebutuhan dasarnya (Arndt, 1987) 
Sedangkan menurut Quibria (1991) dalam Billah (1992:185), beberapa karakteristik kemiskinan di Asia Selatan dan Asia Tenggara sebagai berikut:

1. Kemiskinan lebih banyak ditemui di pedesaan daripada di perkotaan

2. Kemiskinan berkorelasi positif dengan jumlah anggota keluarga dan berkorelasi negatif dengan jumlah pekerja dalam suatu keluarga

3. Kemiskinan ditandai oleh rendahnya pemilikan asset keluarga

4. Pertanian merupakan sumber penghasilan utama bagi rumah tangga miskin

5. Kemiskinan berkaitan dengan masalah sosial budaya yang dinamis.

Sutatwo Hadiwigeno dan Agus Pakpahan (1992:27) dalam mengidentifikasi wilayah miskin di Indonesia, merangkum karakteristik utama wilayah miskin dan perkiraan penyebab utama kemiskinan pada wilayah miskin di Indonesia yang dikelompokkan menurut:

1. Sumber daya alam

2. Teknologi dan unsur pendukungnya

3. Sumber daya manusia

4. Prasarana dan permodalan

5. Prasarana dan kelembagaan

Karakteristik lain dari tingkatan kemiskinan adalah adanya apa yang dinamakan dengan "kemiskinan sementara" dan "kemiskinan kronis". Kemiskinan sementara terjadi karena adanya misal, bencana alam. Sementara kemiskinan kronis terjadi pada mereka yang kekurangan ketrampilan, aset dan stamina. Intensitas kemiskinan pada berbagai bagian masyarakat miskin dapat diukur dengan "Sen Index of Poverty" (Sen, 1973)

\section{Gender dan Kemiskinan}

Ada beberapa alasan yang menyebabkan wanita juga merupakan korban dari kemiskinan. Pertama, wanita bekerja lebih lama daripada laki-laki untuk mencapai tingkat yang sama dalam taraf hidup. Kedua, wanita dihadapkan pada kesempatan yang lebih sedikit untuk melepaskan diri dari kemiskinan, sebagaimana yang diperoleh kaum laki-laki (Haddad, 1991) untuk Ghana, Birdsall dan Behrman (1991)

152 Jurnal Ekonomi Pembangunan Vol.2, No.2, Desember $2001: 148-160$ 
untuk Brazil. Ketiga, dalam beberapa kultur masyarakat, seorang janda menghadapi rintangan yang berat antara bekerja dan menikah lagi, dan ditempatkan sebagai warga kelas dua di dalam rumahnya, menyebabkan tingginya resiko kemiskinan. Studi yang dilakukan di India menunjukkan hal tersebut.

\section{Kemiskinan dan Nutrisi}

Hubungan antara kemiskinan dan nutrisi dapat dilihat secara garis besar dari adanya kekurangan makanan yang mengandung energi daripada yang dibutuhkan oleh tubuh. Batasan minimal setiap individu untuk memenuhi kebutuhan pangan berbeda-beda menurut umur, jenis kelamin, berat badan dan jenis aktivitas yang dilakukan. Secara umum kebutuhan minimal seseorang agar dapat hidup secara normal untuk energi dan protein masing-masing sebesar $2100 \mathrm{k}$ kalori dan 45 gram per kapita per hari.

Batasan kelompok penduduk miskin kaitannya dengan nutrisi.

1. Sajogyo (1997), yang telah menghitung bahwa seseorang dikelompokkan ke dalam:

a. Miskin apabila tingkat pendapatannya lebih kecil dari $320 \mathrm{~kg}$ nilai tukar beras per kapita per tahun untuk pedesaan dan 480 kg untuk perkotaan.

b. Miskin sekali bila seseorang mempunyai pengeluaran $240 \mathrm{~kg}$ nilai tukar beras per kapita per tahun untuk pedesaan dan 360 $\mathrm{kg}$ beras untuk perkotaan.

c. Melarat dengan pengeluaran sebesar $180 \mathrm{~kg}$ beras nilai tukar beras per kapita per tahun untuk pedesaan dan $270 \mathrm{~kg}$ beras untuk perkotaan.

2. Biro Pusat Statistik (BPS)

Menghitung jumlah penduduk yang miskin di Indonesia berdasarkan pengeluaran yang mampu memenuhi kecukupan konsumsi makanan sebanyak $2100 \mathrm{k}$ kalori/kapita/hari ditambah pemenuhan kebutuhan pokok minimum untuk perumahan, bahan bakar, sandang, pendidikan, kesehatan dan transpor (BPS, 1991). Berdasar batasan tersebut, dengan mengggunakan data SUSENAS 1990, BPS menghitung bahwa pendapatan (diproksi dengan tingkat pengeluaran rumah tangga) sebesar Rp. 13.295/kapita/bulan untuk 
daerah pedesaan dan Rp. 20.614/kapita/bulan untuk daerah perkotaan merupakan batas kemiskinan.

3. Lipton (1988) mengajukan batasan bahwa ultrapoverty line adalah 80 persen dari' standar kebutuhan kalori per kapita per hari. Dengan batasan tersebut, batas garis kemiskinan adalah sekitar $1700 \mathrm{k}$ kalori/kapita/hari.

4. Ravallion (1992) menggunakan juga ukuran anthropometric untuk mengukur status gizi bagi anak-anak seperti misalnya ukuran berat-tinggi atau ukuran berat-umur.

\section{PERTUMBUHAN, KETIMPANGAN DAN KEMISKINAN}

Hubungan antara pertumbuhan dan kemiskinan sangat komplek. Bertolak dari penelitian yang telah dilakukan Kuznets (1995, 1963), Chenery dan Syrquin 1975, Ahlu Walia 1976, Papanek 1977 (dalam Lipton, 1995:2602) tentang hubungan antara pembangunan ekonomi dan pembagian pendapatan, Thee Kian Wie berpendapat bahwa "tidak dapat disimpulkan bahwa pertumbuhan ekonomi yang pesat selalu disertai kemerosotan dalam pembagian pendapatan. Hal ini tergantung dari kondisi khusus yang terdapat di masing-masing negara berkembang serta kebijaksanaan ekonomi khusus yang ditempuh berbagai negara tersebut" (Thee Kian Wie, 1981, dalam Billah, 1983: 186).

Namun demikian menurut beberapa pengkritik pembangunan ekonomi bukan saja menyebabkan kenaikan ketimpangan relatif, tetapi lebih parah lagi membawa pula kemerosotan dalam tingkat hidup absolut dari golongan miskin.

Studi yang dilakukan Sritua Arief tentang pertumbuhan ekonomi dan disparitas pendapatan di Indonesia menarik kesimpulan bahwa telah terjadi suatu proses pembiayaan pertumbuhan ekonomi dengan mengorbankan sektor tradisional.

\section{KEBIJAKSANAAN MAKRO EKONOMI, KEMISKINAN DAN CAMPUR TANGAN PEMERINTAH}

Vyas (1992) dalam Billah (1983:187) yang mengemukakan adanya dua pendekatan dalam memberantas kemiskinan. Yang pertama konsep "Trickle Down Efffect" dari pertumbuhan yang cepat yang kedua mendasarkan diri lebih banyak kepada intervensi pemerintah.

154 Jurnal Ekonomi Pembangunan Vol.2, No.2, Desember 2001: 148-160 
Secara historis "tetesan ke bawah" bermanfaat bagi golongan miskin apabila paling tidak salah satu dari dua kondisi di bawah ini dipenuhi yaitu: (a) tingkat pertumbuhan ekonomi cukup tinggi yaitu 8$10 \%$ dan (b) penduduk miskin mempunyai penguasaan asset sumber daya.

Sajogjo (1981:25) mengemukakan kebijakan yaitu:

a. Perlu adanya perubahan-perubahan kelembagaan dalam empat hal yakni produksi, pemasaran, distribusi pengolahan dan konsumsi.

b. Kesempatan kerja dalam penciptaan lapangan kerja memerlukan partisipasi aktif masyarakat.

c. Pijakan yang lain adalah pendekatan kebutuhan dasar dalam bentuk pangan dan kebutuhan-kebutuhan dasar lain seperti kesehatan dan pendidikan.

Irma Adelman mengusulkan untuk mengikuti suatu urutan dinamis dalam strategi pembangunan yaitu :

1. Redistribusi harta produktif utama terutama tanah dan modal fisik (sebagaimana pernah terjadi di Jepang, Taiwan dan Korea).

2. Pengembangan sumber daya manusia atau redistribusi harta non fisik (seperti di Korea Selatan).

3. Industrialisasi dan pertumbuhan yang padat karya. Tingkat kesempatan kerja yang tinggi yang disebabkan oleh industrialisasi akan menyediakan pendapatan yang akan menghasilkan permintaan barang-barang produksi yang dihasilkan dan akan menjamin distribusi keuntungan secara luas (Adelman, 1975).

Michael Lipton (1995) mengemukakan beberapa alternatif solusi pengentasan kemiskinan yang terdiri dari tiga hal yaitu:

1. Labour-intensive growth (instrumen kebijaksanaan, deregulasi, pembangunan infrastruktur, right prices)

2. Human capital formation (pendidikan, dan sebagainya)

3. Social safety net/JPS; kesehatan, jaminan tenaga kerja dan sebagainya.

\section{DESKRIPSI KEMISKINAN DI INDONESIA}

Perkembangan jumlah dan persentase penduduk yang berada di bawah garis kemiskinan secara umum telah berhasil diturunkan selama periode 1976-1996. Berdasarkan perhitungan head count index 
dalam tabel 1, terlihat bahwa terdapat kecenderungan penurunan secara umum tingkat kemiskinan di Indonesia dari tahun 1986-1987.

Dua puluh dari dua puluh enam propinsi telah mampu membebaskan penduđuk miskinnya dari jerat kemiskinan. Bahkan sejumlah propinsi telah mampu mengurangi jumlah dan persentase penduduk miskinnya secara drastis. Akan tetapi ada enam propinsi yang bukan saja gagal mempertahankan persentase jumlah kaum miskinnya, tapi justru semakin buruk penampilannya. Fenomena menarik yang bisa ditemui dari tabel 1 ini adalah ada beberapa propinsi kaya raya yang termasuk dalam kategori gagal mengurangi jumlah penduduknya yang berada di bawah garis kemiskinan. Sementara femomena menarik lainnya adalah bahwa kawasan timur Indonesia tetap merupakan daerah yang bisa diidentikkan dengan kawasan yang lebih banyak penduduk miskinnya, kecuali propinsipropinsi Sulawesi Utara dan Tengah serta Maluku.

Tabel 1. Penduduk di Bawah Garis Kemiskinan Menurut Propinsi, 1976 dan 1987

\begin{tabular}{|c|c|c|c|}
\hline \multirow{2}{*}{ Propinsi } & \multicolumn{2}{|c|}{ Head Count Ratio (\%) } & \multirow{2}{*}{ Perubahan (\%) } \\
\hline & 1976 & 1987 & \\
\hline Jakarta & 3,0 & $\ldots$ & $-\cdots$ \\
\hline DI Aceh & 6,6 & 3.53 & 3.07 \\
\hline Kalimantan Timur & 3.0 & 4.58 & 1.58 \\
\hline Jambi & 10.7 & 5.62 & 5.08 \\
\hline Kalimantan Selatan & 7.2 & 6.01 & 1.19 \\
\hline Sumatera Selatan & 20.0 & 7.54 & 12.46 \\
\hline Sumatera Barat & 14.1 & 7.94 & 7.06 \\
\hline DIY & 27.1 & 8.89 & 18.21 \\
\hline Bengkulu & 16.8 & 9.99 & 6.81 \\
\hline Maluku & 40.1 & 10.45 & 29.65 \\
\hline Sulawesi Utara & 41.3 & 10.80 & 30.50 \\
\hline Jawa Timur & 35.9 & 11.58 & 24.32 \\
\hline Kalteng & 8.0 & 11.58 & -3.58 \\
\hline Kalbar & 15.2 & 12.25 & 2.95 \\
\hline Sulteng & 36.9 & 13.50 & 23.40 \\
\hline Jabar & 15.0 & 14.08 & 0.92 \\
\hline Jateng & 24.6 & 15.33 & 9.27 \\
\hline Sumut & 10.9 & 16.54 & -5.36 \\
\hline Riau & 14.6 & 17.31 & -2.71 \\
\hline Sulsel & 26.2 & 17.78 & 8.52 \\
\hline Bali & 14.0 & 18.31 & -4.31 \\
\hline
\end{tabular}


Lanjutan Tabel 1...

\begin{tabular}{|l|c|c|c|}
\hline \multirow{2}{*}{ Propinsi } & \multicolumn{2}{|c|}{ Head Count Ratio (\%) } & \multirow{2}{*}{ Perubahan (\%) } \\
\cline { 2 - 3 } & 1976 & 1987 & \\
\hline Lampung & 41.4 & 25.89 & 15.49 \\
Sultra & 41.9 & 31.66 & 10.24 \\
Irian Jaya &.-- & 31.98 & -17.15 \\
NTB & 28.1 & 45.25 & -5.61 \\
NTT & 44.3 & 49.91 & \\
\hline Indonesia (rata-rata) & 24.1 & 13.33 & \\
\hline
\end{tabular}

Sumber: Cornelis Lay. 1993. Ketimpangan dan Keterbelakangan di Indonesia. Seri Monograf Fisipol UGM No. 5

Tingkat kemiskinan yang tinggi di kawasan timur Indonesia mengindikasikan bahwa tingkat pendapatan per kapita penduduk di kawasan ini berada jauh di bawah rata-rata nasional. Dan ini mengisyaratkan adanya ketimpangan dalam pendapatan di kawasan Indonesia antara Indonesia Bagian Barat dan Indonesia Bagian Timur.

Keberhasilan Indonesia dalam mengurangi jumlah penduduk yang berada di bawah garis kemiskinan sebelum krisis berlangsung disebabkan oleh strategi pembangunan yang dipilih, yaitu: (1) kebijakan terhadap terhadap pertanian dan pedesaan yang menjadikan dasar yang kokoh untuk penghasilan dan kesempatan kerja di pedesaan, (2) Investasi besar dalam berbagai infrastruktur sosial.

Pada tahun 1976 jumlah penduduk miskin mencapai 54,2 juta $(40,0 \%)$ dengan proporsi daerah perkotaan 10,0 juta $(38,8 \%)$ dan pedesaan sebesar 44,2 juta $(40,4 \%)$. Kondisi kemiskinan pada saat itu dikarenakan tingginya tingkat pertumbuhan ekonomi. Kemiskinan di pedesaan disebabkan oleh lambatnya pertumbuhan produksi beras yang merupakan sumber pendapatan utama penduduk miskin pedesaan. Selain itu, kebanyakan infrastruktur fisik dan sosial baru saja dikembangkan dan manfaat dari investasi tersebut belum dapat dinikmati hasilnya. Sebaliknya di daerah perkotaan mendapat manfat dari pembangunan infrastruktur fisik dan sosial sehingga mendorong pertumbuhan kegiatan ekonomi.

Pada tahun 1987 jumlah penduduk miskin telah berhasil diturunkan menjadi 30 juta orang $(17,4 \%)$. Penurunan penduduk miskin lebih cepat di daerah pedesaan. Hal ini disebabkan karena usaha-usaha yang telah dilakukan oleh pemerintah dalam meningkatkan 
dan memperluas kegiatan pembangunan sampai ke desa-desa mengingat sebagian besar penduduk Indonesia tinggal di pedesaan. Sedangkan penurunan kemiskinan di daerah perkotaan lebih lambat dikarenakan pada tahun-tahun tersebut tingkat pertumbuhan urbanisasi sangat cepat.

Sebagian besar penduduk telah berhasil dientaskan dari garis kemiskinan pada tahun 1996 , menjadi hanya 22,5 juta orang. (11,3\%), dengan 15,3 juta tinggal di pedesaan dan 7,2 juta orang berada di perkotaan.

Tabel 2. Perkembangan Jumlah dan Persentase Penduduk Miskin di Indonesia Tahun 1976-1998

\begin{tabular}{|c|c|c|c|c|c|c|c|c|c|}
\hline \multirow{2}{*}{ Tahun } & \multicolumn{2}{|c|}{ Jumlah Penduduk Miskin } & \multicolumn{3}{c|}{$\begin{array}{c}\text { Persentase Penduduk } \\
\text { Miskin }\end{array}$} & \multicolumn{3}{|c|}{$\begin{array}{c}\text { Jumlah Penduduk } \\
\text { Indonesia }\end{array}$} \\
\cline { 2 - 9 } & Kota & Desa & $\begin{array}{c}\text { Nasio } \\
\text { nal }\end{array}$ & Kota & Desa & $\begin{array}{c}\text { Nasio } \\
\text { nal }\end{array}$ & Kota & Desa & $\begin{array}{c}\text { Nasio } \\
\text { nal }\end{array}$ \\
\hline 1976 & $\begin{array}{c}10,0 \\
(4.522)\end{array}$ & $\begin{array}{c}44,2 \\
(2.849)\end{array}$ & 54,2 & 38,79 & 40,37 & 40,08 & 25,8 & 109,9 & 135,3 \\
\hline 1978 & $\begin{array}{c}8,3 \\
(4.969)\end{array}$ & $\begin{array}{c}38,9 \\
(2.981)\end{array}$ & 47,2 & 30,84 & 33,38 & 33,31 & 26,9 & 116,5 & 141,7 \\
\hline 1980 & $\begin{array}{c}9.5 \\
(6.831)\end{array}$ & $\begin{array}{c}32,8 \\
(4,449)\end{array}$ & 42,3 & 29,04 & 28,42 & 28,56 & 32,7 & 115,4 & 148,1 \\
\hline 1981 & $\begin{array}{c}9,3 \\
(9.777)\end{array}$ & $\begin{array}{c}31,3 \\
(5.877)\end{array}$ & 40,6 & 28,06 & 26,49 & 26,85 & 33,1 & 118,1 & 151,2 \\
\hline 1984 & $\begin{array}{c}9,3 \\
(13,731)\end{array}$ & $\begin{array}{c}25,7 \\
(7.746)\end{array}$ & 35,0 & 23,14 & 21,18 & 21,64 & 40,2 & 272,5 & 161,7 \\
\hline 1987 & $\begin{array}{c}9,7 \\
(17.381)\end{array}$ & $\begin{array}{c}20,3 \\
(10.294)\end{array}$ & 30,0 & 20,14 & 16,14 & 17,42 & 48,2 & 124,6 & 172,2 \\
\hline 1990 & $\begin{array}{c}9,4 \\
(20.614)\end{array}$ & $\begin{array}{c}17,8 \\
(13.295)\end{array}$ & 27,2 & 16,75 & 14,33 & 15,08 & 56,1 & 124,2 & 180,3 \\
\hline 1993 & $\begin{array}{c}8,7 \\
(27.905)\end{array}$ & $\begin{array}{c}17.2 \\
(18.244)\end{array}$ & 25,9 & 13,45 & 13,79 & 13,67 & 63,6 & 124,7 & 188,3 \\
\hline 1996 & $\begin{array}{c}7,2 \\
(38.246)\end{array}$ & $\begin{array}{c}15,3 \\
(72.780)\end{array}$ & 22,5 & 9,71 & 12,30 & 11,34 & 74,1 & 124,4 & 198,5 \\
\hline 1998 & $\begin{array}{c}(17,6) \\
(96.959)\end{array}$ & $\begin{array}{c}31,9 \\
(72.780)\end{array}$ & 49,5 & 21,9 & 25,7 & 24,2 & 80,3 & 124,1 & 204,4 \\
\hline
\end{tabular}

Catatan: Angka dalam kurung merupakan batas garis kemiskinan

Sumber: - BPS (1997) Peta dan Perkembangan Kemiskinan Indonesia

- BPS (1999) The 1998 Revised Poverty Incidence Based on The December 1998 Susenas: A Methodological Issue.

Keberhasilan dalam pengentasan kemiskinan pada tahun 1996 berakhir, karena pada tahun 1997, Indonesia dilanda krisis ekonomi

158 Jurnal Ekonomi Pembangunan Vol.2, No.2, Desember 2001 : 148-160 
besar-besaran yang menyebabkan jatuhnya penduduk ke dalam jurang kemiskinan hingga mencapai 49,5 juta orang pada tahun 1998 sebagaimana terlihat dalam tabel 2.

\section{KESIMPULAN}

1. Masalah kemiskinan adalah masalah global umat manusia. Artinya, masalah kemiskinan bukanlah masalah individu melainkan merupakan masalah sistem kemasyarakatan di suatu wilayah atau negara tertentu, yang juga berkaitan erat dengan sistem dan struktur perekonomian dunia secara menyeluruh.

2. Kemiskinan merupakan suatu proses dinamis yang berkembang menurut perubahan hubungan politik dan ekonomi antar negara di dunia. Kemiskinan juga merupakan salah satu bentuk kegagalan dari sistem perekonomian pasar bebas.

3. Kemiskinan di dunia ditandai oleh adanya ketimpangan yang tajam, terutama ketimpangan pendapatan perkapita antara negara maju dan negara berkembang. Perkembangan ekonomi menunjukkan bahwa ketimpangan antar negara berkembang akan semakin meningkat di masa yang akan datang.

4. Walaupun sudah banyak upaya dilakukan secara internasional untuk menanggulangi kemiskinan dan keterbelakangan ini, namun hasil yang dicapai belum seperti yang diharapkan. Karena itu penanggulangan kemiskinan hendaknya tidak tergantung sepenuhnya dengan bantuan dari luar, melainkan harus dilandasi oleh kemampuan mandiri dari masing-masing negara berkembang.

5. Mengingat bahwa kemiskinan harus ditanggulangi melalui pembangunan nasional, mempunyai posisi yang paling strategis dalam upaya penanggulangan kemiskinan.

6. Pengembangan dan pemanfaatan teknologi merupakan salah satu upaya yang memberi peluang untuk meningkatkan produktivitas tenaga kerja karena itu, pengembangan ilmu pengetahuan dan teknologi merupakan salah satu faktor penentu dalam penanggulangan kemiskinan.

7. Mengingat bahwa sebagian besar penduduk miskin hidup di pedesaan dan memperoleh pendapatan dari sektor pertanian, serta mengingat bahwa masalah kecukupan pangan merupakan masalah 
kritis, maka pembangunan pertanian mempunyai peran yang strategis dalam upaya penanggulangan kemiskinan.

\section{DAFTAR PUSTAK $\check{A}$}

H.S. Dillon \& Hermanto. 1993. Kemiskinan di Negara Berkembang. Prisma, 12(3):11-21.

Lay, Cornellis. 1993. Ketimpangan dan Keterbelakangan di Indonesia. Seri Monograf Fisipol UGM No. 5.

Lipton \& Ravalion. 1995. Poverty and Policy. Dalam Chenery and Srinivasan, Handbook of Development Economics, Volume IIIB, Amsterdam, Netherland:Elsevier Science B.V.

Lipton, Michael. 1977. Why Poor People Stay Poor, Urban Bias in World Development. London:Temple, Smith.

M.M. Billah. 1983. Kemiskinan dan Ketimpangan Pendapatan. Dalam Pertumbuhan dan Pemerataan dalam Pembangunan Pertanian. Jakarta:Perhimpunan Ekonomi dan Pertanian Indonesia (PERHEPI)

Muin Pabinru \& Handewi P. Saliem. 1993. Kecukupan dan Ketahanan Pangan. Prisma, 12(3):33-43.

Sajogyo. 1981. Pendekatan Kebutuhan Dasar Manusia Bagi Perbaikan Keadaan Gizi Kaum Miskin. Agro-Ekonomika, 12(15):5-25.

Soetatwo Hadiwigeno \& Agus Pakpahan. 1993. Identifikasi Wilayah Miskin di Indonesia. Prisma, 12(3):23-32.

World Bank. 1990. World Development Report 1990.

160 Jurnal Ekonomi Pembangunan Vol.2, No.2, Desember $2001: 148-160$ 